\title{
Marketing Myopia in Brazilian Public Universities: An Empirical Study Involving Academicians
}

\author{
Dalton Sousa ${ }^{1}$, André Zambalde 2 , Gustavo Souki ${ }^{3}$ Ricardo Veroneze $e^{4 *}$
}

\begin{abstract}
The objective of this study was to understand the role of marketing, from research to commercialization of technologies in Brazilian public universities. To that end, an online survey was conducted, involving 236 academicians associated with in Brazilian public universities. The data obtained were subjected to exploratory factor analysis and descriptive statistics. The results revealed the low utilization of proactive market analyses in Brazilian public universities, as well as the limited integration of marketing through interaction with companies. The strategic orientation prevalent in BPUs was geared to technology, at the expense of relationships with society and the market. An entrepreneurial orientation was not observed. The actions to promote or encourage the transfer of Brazilian public universities technologies to the market proved timid. Finally, there were several obstacles to the implementation of marketing in Brazilian public universities, characterizing the so called marketing myopia.
\end{abstract}

Keywords: patent innovation; factorial analysis; entrepreneurship; technology transfer; market orientation.

Submitted: April $17^{\text {th }}, 2018$ / Approved: July $5^{\text {th }}, 2018$

\section{Introduction}

Universities have their roles to support teaching, research, and extension. However, the current rapid technological advancement has increased the demand for universities to collaborate to economic progress by utilizing technical and scientific skills to develop technologies that generate value for society when transformed into innovation. Thus, universities seek to convert their role from generators and accumulators of knowledge, distant from society, to knowledge centers with a prominent function in the Brazilian National Systems of Innovation (NSI) (Calderon-Martinez \& Garcia-Quevedo, 2013; Marozau, Guerrero, \& Urbano, 2016). The NSI includes public and private institutions that interact and form a network for scientific and technological development in the country, which is achieved through innovations (Pereira, Franco, Santos, \& Vieira, 2015).

In this direction, an important milestone was the Bayh-Dole Act that was passed in the United States (US) in 1980. It led to increase American commercialization of science and other forms of university technology transfer, which influenced the introduction of similar laws in other countries. An increase in university patenting, licensing, and forming spinoff/startup companies also began to be observed in many other countries (Siegel \& Wright, 2015).

In turn, Brazil has adopted legislation on the intellectual property assigned to universities, inspired by the US model. However, its universities are just beginning the work of intellectual protection and commercialization of technologies, which has a long way to go to be fully realized (Sousa, Veroneze, Zambalde, \& Bermejo, 2015; Stal \& Fujino, 2016). Thus, in the Brazilian context, there is the challenge of transforming science into technology that reaches markets because universities are normally responsible for research but do not always have the same capacity for the development of marketable inventions. After all, there are several paths and barriers in the industrial process or any other means of commercial application, from the discovery or scientific development of a particular technology until the product reaches the shop shelves (Siegel, Waldman, \& Link, 2003; Stal \& Fujino, 2016).

This situation suggests that universities should expand their relationships and practices, as well as allow their professors, researchers, and academicians alternative forms of professional performance to meet the needs and desires of society and public and private organizations (Payumo et al., 2012; Sousa et al., 2015; Veroneze, 2016). From the perspective of marketing in Brazilian public universities, it can be a problem for the already developed technology to become an innovation. The reason is that the goal of knowing and understanding customers so that the product meets their needs and sells by itself may have been ignored since the early stages of research (Lee, 2013; Mohr \& Sarin, 2009). In his classic article that suggests the myopia of marketing in companies, Levitt warns "the marketing effort is still viewed as a necessary consequence of the product - not vice versa, as it should be" (2004, p. 144). Thus, it becomes necessary to understand the perceptions of the researchers and/or professors in Brazilian public universities regarding marketing and their potential contributions to the process of innovation, development, and commercialization of technologies (Sousa et al., 2015; Veroneze, 2016; Veroneze, Zambalde, Sousa, \& Rennó, 2017).

It is believed that marketing must contribute to perceptions and actions on the complexities of the market and of society in general for the development of technologies in public universities (Smith, Drumwright, \& Gentile, 2010; Veroneze et al., 2017; Wirtz, Tuzovic, Sven, \& Kuppelwieser, 2014). Thus, this work's general aim was to understand the role of marketing, from research to commercialization of technologies in Brazilian public universities. In this context, this study's specific aims were as follows:

(1) Campus de Paranaíba, Universidade Federal de Mato Grosso do Sul, Paranaíba, Mato Grosso do Sul, Brazil.

(2) Departamento de Ciência da Computação, Universidade Federal de Lavras, Campus Universitario, Lavras, Minas Gerais, Brazil.

(3) Faculdade de Ciências Gerenciais. Centro Universitário UNA, Belo Horizonte, Minas Gerais, Brazil.

(4) Departamento de Ciências Gerenciais e Humanas, IFMG, Campus Bambuí, Rodovia, Minas Gerais, Brazil.

${ }^{*}$ Corresponding author: rbveroneze@gmail.com 
1. Investigate the existence of proactive market analysis in the context of applied research.

2. Check the integration of marketing, from research until the commercialization of technologies.

3. Identify the presence of a strategic orientation of marketing in the development of applied research.

4. Identify the marketing practices used to promote the commercialization of the developed technologies.

5. Know the obstacles faced by marketing from the survey until the commercialization of technologies.

To meet the proposed objectives, a survey was conducted that included the application of a framework, based on a literature review (Bodlaj, 2010; Bouncken, Plüschke, Pesch, \& Kraus, 2016; Coviello, Brodie, Danaher, \& Johnston, 2002; Jeong, Pae, \& Zhou, 2006; Kaymaz \& Eryiğit, 2011; Kerr \& Patti, 2015; Klein, Haan, \& Goldberg, 2010; Malvezzi, Zambalde, \& Rezende, 2014; Matsuno, Zhu, \& Rice, 2014; Mu, 2015; Nabi \& Liñán, 2013; Siegel et al., 2003). Such a framework comprised the following factors:

1. proactive market analysis (market sensing);

2. marketing-research integration by means of:

a) organizations external to universities and

b) technological innovation centers (TICs);

1. strategic orientation of marketing in research, involving:

c) technology,

d) consumers/citizens, and

e) entrepreneurs;

1. contemporary marketing practices; and

2. obstacles to marketing, from research until the technologies' commercialization.

This paper is structured as follows. It presents the introduction, followed by the theoretical foundation, which deals with the evolution of marketing, the expansion of its role to serve the interests of society as a whole, and the need for its application in the context of universities, in addition to the framework that guided the research. Next, the methodological procedures and the research results are discussed. The concluding section covers the final considerations, academic and managerial implications, research limitations, and suggestions for future research.

\section{Theoretical background}

This section explains the evolution of the concepts of marketing and its relationship with the current demand for universities' greater contributions to innovation. The framework that guided the development of the research is also presented.

\section{Marketing, society, and universities}

Since its origins, marketing has been characterized as an area of knowledge that seeks to monitor society's progress and problems, constantly re-examining its focus, techniques, and targets (Kotler, 1972).

Thus, the American Marketing Association's definition of current marketing attempts to capture its broader nature: "Marketing is the activity, set of institutions, and processes for creating, communicating, delivering, and exchanging offerings that have value for customers, clients, partners, and society at large" (2015). Therefore, the essence of marketing - to interact with customers and meet their needs and those of society in general-has evolved together with its concept, since the endeavors originate from the pursuit to meet customers' needs and desires (Levitt, 2004; Smith et al., 2010). In this direction, Levitt (2004) argues that the industry must be developed from the customers' needs, offering products and/or services capable of satisfying them. Only from there should other concerns arise, such as research and development, the production process, and sales.

In this way, the myopia of marketing is possibly the idea of more influential marketing since its publication, being a true watershed between the approach of production/sales and the orientation of marketing (Baker, 2003; Smith et al., 2010). Since then, a lot of professionals and organizations have succeeded in focusing on consumers' needs. However, researchers should look for a new type of marketing myopia in today's business environment, that is, the lack of vision for a broad social context in decision making (Smith et al., 2010). In this regard, the role of universities in the NSI began to require an understanding of the possible contributions of marketing, from research to commercialization of technologies (Malvezzi \& Zambalde, 2013; Malvezzi et al., 2014; Sousa et al., 2015; Veroneze et al., 2017).

In universities, marketing can contribute to catalyzing innovations from the overflow of scientific knowledge in various ways, such as licensing patents and forming startups or spinoffs, in line with the real needs of the markets and society (Hsu, Shen, Yuan, \& Chou, 2015; Sousa et al., 2015; Veroneze et al., 2017; Wirtz et al., 2014).

\section{Proposed framework and its principles}

This study's proposed framework for application in Brazilian public universities is based on the theoretical review of the role of marketing, from research to commercialization of technologies (Bodlaj, 2010; Bouncken et al., 2016; Coviello et al., 2002; Jeong et al., 2006; Kaymaz \& Eryiğit, 2011; Kerr \& Patti, 2015; Malvezzi et al., 2014; Matsuno et al., 2014; Mu, 2015; Nabi \& Liñán, 2013; Siegel et al., 2003), as presented in Figure 1. 
Figure 1. Role of marketing in Brazilian public universities (framework)

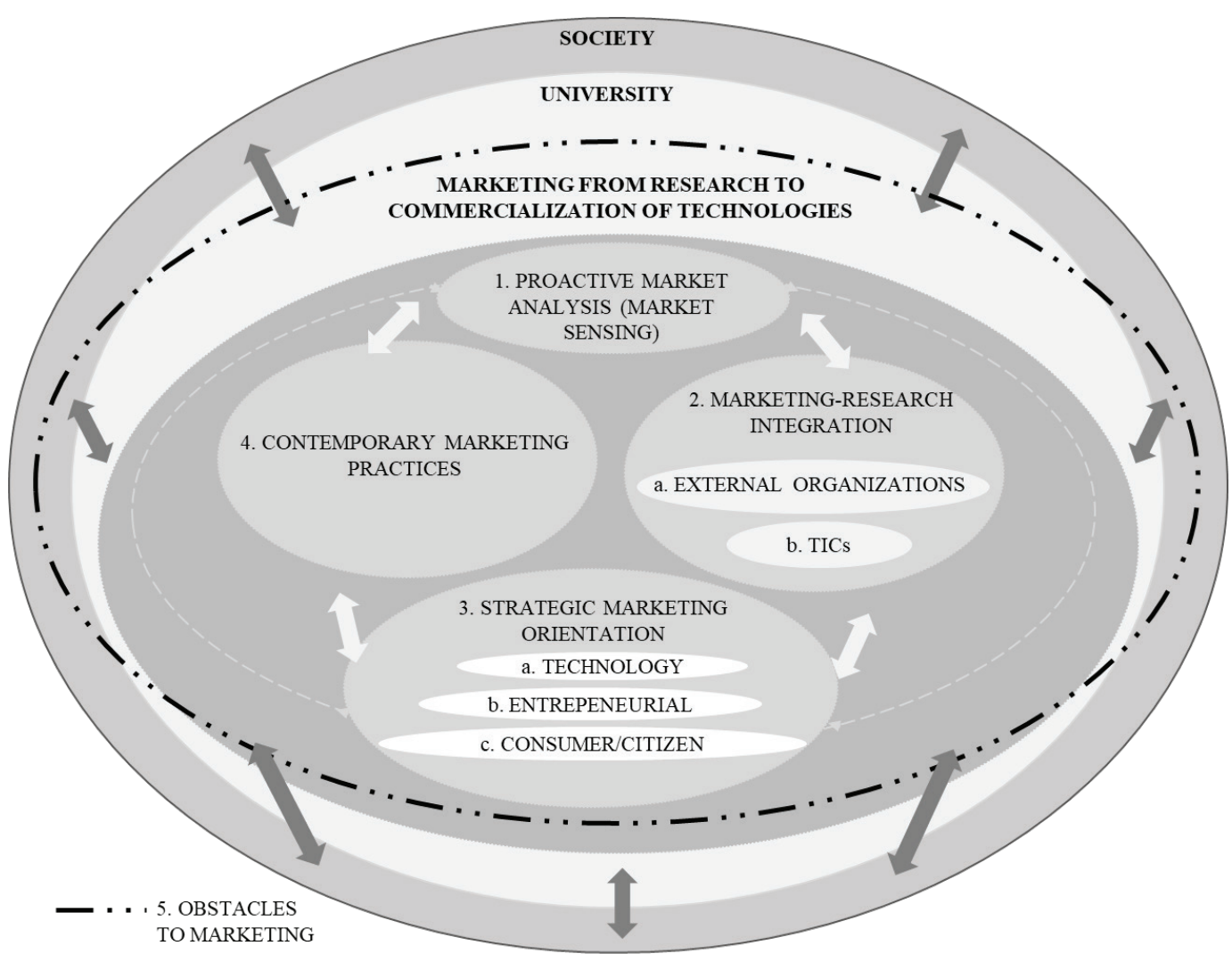

Source: Developed by the authors based on the previously cited references

The proposed framework is based on the premise that the university is an integral part of society and points to the imperative of understanding its needs, through marketing, for the development of appropriate solutions, despite the possible obstacles. The framework's first component is (1) proactive market analysis (market sensing) (Bodlaj, 2010; $\mathrm{Mu}, 2015)$ since market orientation is the heart of modern marketing and can decisively contribute to business performance (Gummesson, 1991; Narver \& Slater, 1990). The guidance for the market highlights the importance of customers and external information in creating value for customers and developing competitive advantages for organizations. Thus, the superior performance of an organization comes from its ability to detect, define, and manage customers' expectations for the delivery of superior value to them $(\mathrm{Mu}, 2015)$.

If a university does not understand the needs and desires of society and/or the markets, the development of technologies may result in failure in their commercialization, unnecessary costs of intellectual protection of products that will have no market demand, and therefore, a delay in the economic development of a country (Bodlaj, 2012; Veroneze, 2016; Veroneze et al., 2017). A relevant concept presented in the literature is market sensing, which is a marketing capability that enables an organization to forecast and act on trends, signs, and events that may indicate changes in consumers' needs and market settings (Baker, 2003; Mu, 2015; Mu \& Di Benedetto, 2011).
It seems natural for universities to make use of market sensing. It would enable universities to anticipate the evolution of markets and their emerging opportunities for the development of technologies from a long-term perspective-based on information obtained from their complex business ecosystems-or of society as a whole $(\mathrm{Mu}$, 2015; Mu \& Di Benedetto, 2011; Sousa et al., 2015). On the other hand, marketing integration to obtain knowledge about the market, from the research until the commercialization of technologies, can occur in an indirect form in universities, but it can be triggered by means of partnerships with companies and/or the TICs' operations.

The framework's second component is (2) marketing-research integration by means of relationships or partnerships with businesses and the TICs' operations (Kerr \& Patti; 2015; Matsuno et al., 2014), through which the role of marketing can be put into practice in the context of universities. This is because business partnerships can be effective for the marketing feasibility of technologies developed in universities. On the other hand, as structures specializing in the intellectual property protection and transfer of knowledge from universities, the TICs should also acquire marketing skills to fulfill their mission effectively (Hsu et al., 2015; Stal \& Fujino, 2016; Veroneze et al., 2017; Weckowska, 2015).

In this sense, a relevant concept is science-to-business, which goes beyond the traditional view of the protection and commercialization of 
technologies developed by universities. It deals with the identification of potential users and customers, attempting an early anticipation of the potential applications and benefits of scientific research results in market terms (Boehm \& Hogan, 2013; Kliewe, Baaken, \& Kesting, 2012).

The adoption of conceptual assumptions of marketing in research and development, for the purpose of generating new technologies, allows the projects developed by universities to align better with society's demands and market opportunities (Becker \& Lillemark, 2006; Griffin \& Hauser, 1996; Matsuno et al., 2014). The integration of marketing and research has the goal of increasing the probability of success of new products in the market. This can occur through joint responsibility in defining the aims and priorities of the research and development of new products, enhancing existing products, and understanding consumers and cooperative activities (Becker \& Lillemark, 2006; Griffin \& Hauser, 1996). With marketing knowledge permeating universities, from research to commercialization of technologies, some kind of strategic marketing orientation is expected to guide technology development.

The third component of the proposed framework is (3) strategic marketing orientation, entailing the strategic guidelines that direct and influence the activities of all organizations, either explicit or implicit, aiming at viability and performance. After all, strategic guidance directs the support for and the allocation of resources in organizations, referring to a lasting direction of thought that leads to action (Hakala, 2011; Jeong et al., 2006). The strategic marketing orientation proposal seeks to identify specific guidance in the development of technologies in universities, involving: a) consumers/citizens, b) technology, and c) entrepreneurs (Bouncken et al., 2016; Jeong et al., 2006; Nabi \& Liñán, 2013).

The consumer/citizen orientation focuses on the desires, needs, and interests of this sector. In turn, the technology orientation indicates an organization's tendency or desire to bring innovations to the market, comprising products, processes, or services. The entrepreneurial orientation concentrates on changing and shaping the environment, exploring the opportunities available for people and organizations, applying new and creative ideas with the potential to cause changes in the market, acting proactively, and anticipating future demands (Bouncken et al., 2016; Hakala, 2011). It is believed that as the marketing orientation starts to integrate the research in universities, the marketing practices will be aligned strategically for success in the commercialization of technologies.

Thus, the fourth component of the framework is characterized as the set of (4) contemporary marketing practices because it also seeks to understand the type of marketing practice used in universities in relation to the commercialization of technologies originating from research. This element is based on the vision of Brodie and Coviello (2008), Coviello and colleagues (2002), and Coviello, Brodie, and Munro (1997), who classify contemporary marketing practices into two broad perspectives, divided into four types of marketing: 1) transactional marketing (a. transactions marketing) and 2) relatio- nal marketing (b. database marketing, c. interactive marketing, and d. network marketing). The purpose is to classify the tendency for each practice in the Brazilian universities identified in the literature (Malvezzi \& Zambalde, 2013; Malvezzi et al., 2014; Veroneze, 2016), in line with contemporary marketing practices (Brodie \& Coviello, 2008; Coviello et al., 2002; Coviello et al., 1997).

On the other hand, there are countless challenges and obstacles to marketing in this context. Therefore, the fifth and last component of the framework is proposed as (5) obstacles to marketing, from research until the commercialization of technologies in the universities (Kaymaz \& Eryiğit, 2011; Klein et al., 2010; Nabi \& Liñán, 2013; Siegel et al., 2003).

\section{Method}

To meet the overall objective of understanding the role of marketing, from research to commercialization of technologies in Brazilian public universities, a descriptive-like research was carried out by means of a survey. Such research counted on self-reporting electronic spreadsheets, which were made available on the internet for academicians involved in projects involving research, development, and commercialization of technologies affiliated with several Brazilian public universities. Specifically, the following were included in the sample: (1) professors, researchers, and students in Brazilian public universities who were identified as inventors of patents filed by the National Institute of Intellectual Property (Instituto Nacional da Propriedade Industrial, INPI), for which universities are defined as depositors; (2) professors and leaders of research groups who are active in the Directory of Research Groups of the National Council for Scientific and Technological Development (Conselho Nacional de Desenvolvimento Científico e Tecnológico, $\mathrm{CNPq}$ ) and deal with the theme of innovation; and (3) officers and employees of TICs in Brazilian public universities. To describe the role of marketing in a structured way, we opted to develop a quantitative and descriptive research (Malhotra, Rocha, Laudisio, Altheman, \& Borges, 2005).

As mentioned, the field survey was conducted online using the SurveyMonkey tool, between November 2016 and January 2017. The respondents were sent an email invitation to participate in the research. The database for the recruited sample was generated from internet searches, comprising 3,173 faculty members, researchers, and graduate students from Brazilian public universities. In total, 303 questionnaires were filled in and returned; however, after excluding those that were incomplete or inappropriately filled in, the final sample was reduced to 236 completed questionnaires, which were used in the analysis.

Taking into account the framework proposed in Figure 1, the instrument for the data collection consisted of 26 indicators, including the following factors: (1) proactive market analysis (market sensing), (2) marketing-research integration (external organizations and TICs), and (3) strategic marketing orientation (entrepreneurial, consumer/ citizen, and technology). Additionally, 14 questions were included that formed the block on (4) marketing practices in universities and 
19 other issues, corresponding to the possible (5) obstacles to marketing for the interactions among the universities, markets, and society for the development and commercialization of technologies.

In these first five blocks, responses indicating agreement or disagreement on a five-point scale were used, from 1 = "strongly disagree" to 5 = "completely agree." As Antonialli, Antonialli, and Antonialli recommend (2017), this method assumed the ordinal scale of agreement or disagreement to be by intervals. The last block comprised 11 questions about the respondents' profiles.

The data were analyzed by means of basic descriptive statistics, such as frequency distributions, averages, standard deviations and tables crossing, as well as exploratory factorial analysis (EFA). The EFA allowed synthesizing the research variables in a smaller set of common latent dimensions, called factors. For the extraction of the fac- tors, the method of principal components was used, and the rotation used was the Varimax (Hair Jr., Anderson, Tatham, \& Black, 2005). The constitution of the factors contributed to understanding the marketing role, from the research until the commercialization of technologies in Brazilian public universities, by also allowing the evaluation of the degree of its application in this context.

\section{Results and Analyzes}

The sample comprised respondents representing 48 academic fields and 57 Brazilian public universities. Table 1 presents the profiles of the sample, plus the details of the respondents with or without patents filed (under review or already granted). Overall, 236 valid questionnaires were obtained, considering that due to some issues about the respondents' profiles (e.g., privacy or confidentiality), several questions were allowed to be unanswered. The main characteristics are discussed next.

Table 1. Sample characterization

\begin{tabular}{|c|c|c|c|c|c|c|c|c|c|}
\hline \multirow{3}{*}{ Variables } & \multicolumn{9}{|c|}{ Does it have a patent (under review or already granted)? } \\
\hline & Yes & $\%$ & No & $\%$ & Subtotal & $\mathbf{N R}^{1}$ & $\%$ & $\%$ & Total \\
\hline & 185 & 78.39 & 49 & 20.76 & 234 & 2 & 0.85 & 100 & 236 \\
\hline Bachelor's Degree & 5 & 2.12 & 4 & 1.69 & 9 & \multirow{3}{*}{2} & & & \multirow{3}{*}{236} \\
\hline Master's Degree & 16 & 6.78 & 11 & 4.66 & 27 & & 0.85 & 100 & \\
\hline Doctoral Degree & 164 & 69.49 & 34 & 14.41 & 198 & & & & \\
\hline Professor & 124 & 52.54 & 34 & 14.41 & 158 & \multirow{5}{*}{3} & & & \multirow{5}{*}{236} \\
\hline $\begin{array}{l}\text { Administrative staff } \\
\text { members and technicians }\end{array}$ & 2 & 0.85 & 3 & 1.27 & 5 & & 1.27 & 100 & \\
\hline TIC employee & 2 & 0.85 & 4 & 1.69 & 6 & & & & \\
\hline Undergraduate student & 1 & 0.42 & 0 & 0.00 & 1 & & & & \\
\hline Other & 8 & 3.39 & 0 & 0.00 & 8 & & & & \\
\hline Consulting (no) & 110 & 46.61 & 25 & 10.59 & 135 & 2 & 0.85 & 100 & 236 \\
\hline Male & 108 & 45.76 & 31 & 13.14 & 139 & \multirow{2}{*}{3} & \multirow{2}{*}{1.27} & \multirow{2}{*}{100} & \multirow{2}{*}{236} \\
\hline Female & 76 & 32.20 & 18 & 7.63 & 94 & & & & \\
\hline Research group leader & 104 & 44.07 & 31 & 13.14 & 135 & \multirow{2}{*}{2} & \multirow{2}{*}{0.85} & \multirow{2}{*}{100} & \multirow{2}{*}{236} \\
\hline Non-leader of research group & 81 & 34.32 & 18 & 7.63 & 99 & & & & \\
\hline Already transferred/licensed patent & 28 & 15.14 & 156 & 84.32 & 184 & 1 & 0.54 & 100 & 185 \\
\hline Tutors graduate students & 127 & 53.81 & 25 & 10.59 & 152 & \multirow{2}{*}{35} & \multirow{2}{*}{14.83} & \multirow{2}{*}{100} & \multirow{2}{*}{236} \\
\hline Does not tutor graduate students & 32 & 13.56 & 17 & 7.20 & 49 & & & & \\
\hline Participates in spinoff & 25 & 10.59 & 1 & 0.42 & 26 & 9 & 3.81 & 100 & 236 \\
\hline
\end{tabular}

${ }^{1}$ Did not answer (No response).

Source: Research data 
The majority of the respondents comprised doctors with patents (69.49\%), followed by doctors without patents (14.41\%) and master's students with patents (6.78\%). The professors represented $66.95 \%$ of the sample, $52.54 \%$ with patents and $14.41 \%$ without patents. The respondents who had already conducted research under contract and had patents comprised $36.44 \%$ of the sample, while those who had not yet undertaken research under contract but had patents made up $41.95 \%$. The respondents who had patents and had already done consulting work totaled $31.78 \%$ of the sample, while those who possessed patents but had not yet taken on consulting jobs comprised $46.61 \%$. Among the 185 respondents with patents, only 28 (15.14\%) had already transferred/licensed their patents, and only 25 reported participating in a spinoff/startup, representing only $13.51 \%$ of this group $(25 \div 185)$ and highlighting the low level of entrepreneurship in the academic environment.

\section{Factors related to marketing, from research until commer- cialization of technologies in Brazilian public universities}

To achieve the first three specific goals of this study (check the existence of proactive market analysis in the research context, verify the existence of marketing integration, and identify the presence of a strategic orientation of marketing in the development of applied research in Brazilian public universities, from the research until the commercialization of technologies), EFA was used. In such factorial analysis, 26 variables of the scales proposed were used, which generated an average of 9.08 respondents per variable $(263 \div 26)$, slightly below the ideal proportion of ten respondents per variable suggested by Hair Jr. and colleagues (2005). The Kaiser-Meyer-Olkin (KMO) test result was 0.904 , a value within the excellence zone of sampling adequacy (Field, 2009). In turn, the result of Bartlett's test of sphericity was significant (Sig. 0.000), corroborating the use of EFA.

Six factors were extracted (Table 2), with a total explained variance of $73.082 \%$. Cronbach's alpha value for the totality of the variables was 0.941, indicating coherence in the respondents' answers (Field, 2009). Table 2 also verifies the general view of the answers to each factor, allowing visualization of the discordance or concordance factor regarding the affirmative presented. Given that the scale ranges from $1=$ total discordance to $5=$ total concordance, the value of three (3) indicates an average point between the extremes.

Table 2. Factorial analysis

\begin{tabular}{|c|c|c|c|c|c|c|}
\hline Factors & Indicators & Factorial load & Average & Standard deviation & Factors' average & Cronbach's alpha \\
\hline \multirow{5}{*}{ Proactive market analysis (market sensing) } & B1.3 & 0.812 & 2.83 & 1.10 & \multirow{5}{*}{2.87} & \multirow{5}{*}{0.900} \\
\hline & $\mathrm{B} 1.4$ & 0.771 & 2.92 & 1.15 & & \\
\hline & B1.5 & 0.748 & 2.76 & 1.15 & & \\
\hline & B1.1 & 0.720 & 2.87 & 1.07 & & \\
\hline & $\mathrm{B} 1.2$ & 0.681 & 2.99 & 1.12 & & \\
\hline \multirow{5}{*}{$\begin{array}{l}\text { Marketing-research integration (external } \\
\text { organizations) }\end{array}$} & B2.1 & 0.838 & 3.24 & 1.20 & \multirow{5}{*}{2.88} & \multirow{5}{*}{0.874} \\
\hline & B2.2 & 0.774 & 3.16 & 1.22 & & \\
\hline & $\mathrm{B} 2.3$ & 0.713 & 2.64 & 1.14 & & \\
\hline & B2.4 & 0.621 & 2.82 & 1.16 & & \\
\hline & B2.5 & 0.605 & 2.57 & 1.09 & & \\
\hline \multirow{4}{*}{ Marketing-research integration (TICs) } & B3.3 & 0.861 & 2.87 & 1.13 & \multirow{4}{*}{3.03} & \multirow{4}{*}{0.910} \\
\hline & B3.4 & 0.855 & 2.90 & 1.18 & & \\
\hline & B3.2 & 0.829 & 2.94 & 1.09 & & \\
\hline & B3.1 & 0.728 & 3.42 & 1.17 & & \\
\hline \multirow{4}{*}{ Consumer/citizen orientation } & B4.7.c & 0.808 & 2.88 & 1.19 & \multirow{4}{*}{2.88} & \multirow{4}{*}{0.923} \\
\hline & B4.6.b & 0.773 & 3.08 & 1.25 & & \\
\hline & B4.5.a & 0.748 & 2.86 & 1.18 & & \\
\hline & B4.8.d & 0.738 & 2.71 & 1.15 & & \\
\hline \multirow{4}{*}{ Entrepreneurial orientation } & B4.3.c & 0.837 & 1.93 & 1.03 & \multirow{4}{*}{2.27} & \multirow{4}{*}{0.778} \\
\hline & B4.4.d & 0.754 & 2.04 & 1.02 & & \\
\hline & B4.2.b & 0.722 & 2.35 & 1.09 & & \\
\hline & B4.1.a & 0.483 & 2.75 & 1.14 & & \\
\hline \multirow{4}{*}{ Technology orientation } & B4.9.a & 0.828 & 3.63 & 1.18 & \multirow{4}{*}{3.29} & \multirow{4}{*}{0.844} \\
\hline & B4.10.b & 0.813 & 3.38 & 1.09 & & \\
\hline & B4.11.c & 0.772 & 3.32 & 1.21 & & \\
\hline & B4.12.d & 0.558 & 2.84 & 1.16 & & \\
\hline
\end{tabular}

Note: Cronbach's alpha ( $\alpha$ ) for total (26 items): 0.941. Extraction method: Analysis of principal component.

Rotation method: Varimax with Kaiser normalization; rotation converged in 7 iterations.

Source: Research data 
The first factor extracted comprised the originally proposed five variables, adapted from the works of $\mathrm{Mu}$ (2015) and Bodlaj (2010) Thus, the proactive market analysis (market sensing) had an average of 2.87, lying mainly in the area of disagreement regarding its existence in Brazilian public universities. This finding demonstrates the dissonance among the fundamental precepts of marketing and the development of technology in Brazilian public universities, highlighting these institutions' inability to anticipate and act on trends, signs, and events that permeate the evolution of the needs of the markets and society (Mu, 2015; Mu \& Di Benedetto, 2011).

The second factor extracted, composed of five variables, was entitled as marketing-research integration (external organizations). This factor originated from the scales proposed by Matsuno and colleagues (2014) and Kerr and Patti (2015), and refers to the understanding that marketing may be present in universities, through research, interactions with organizations (companies, hospitals, cooperatives, etc.) and increasing accessibility to the needs, desires and demands of the market / society. The average number of responses to this factor (2.88) was in the area of disagreement, demonstrating the respondents' tendency to disagree about the existence of marketing-research integration by means of interaction with various organizations. This result demonstrates that academicians from Brazilian public universities still do not understand the importance of greater interaction with organizations in the various sectors of the economy to develop technological research that meets the needs and demands of business and society as a whole. This situation reinforces the need for the stimulation of the university-industry interaction in Brazil, as well as the development of a share of science with a business focus, which can be a viable path for the university researchers who are more apt for a marketable interaction (Boehm \& Hogan, 2013; Ismail, Nor, \& Sidek, 2015; Kliewe et al., 2012; Stal \& Fujino, 2016).

The third factor extracted, marketing-research integration (TICs), aimed to verify if the role of marketing in research can be performed in universities through the interaction between the TICs and the researchers/research groups, for the purpose of understanding and meeting the needs, wants, and demands of the market and/or society as a whole. The proposed scale comprised four variables and was adapted from the work of Matsuno and colleagues (2014).

The overall average of the responses to the third factor was 3.03, in the area of neutrality (neither agree nor disagree) but with a slight tendency to agreement. This shows that the TICs can offer a natural path for the adoption of marketing, from research until the commercialization of technologies in Brazilian universities. However, in their patenting, the TICs still seemed focused on intellectual protection of existing technologies, acting more bureaucratically than mercadologically (Stal \& Fujino, 2016; Veroneze, 2016; Veroneze et al., 2017). The last three factors extracted concerned the type of strate- gic marketing orientation (consumer/citizen, technology, and entrepreneurial), observed in Brazilian public universities, for technologies originating from the body of research. The questions were adapted from the works of Bouncken and colleagues (2016), Jeong and colleagues (2006), and Nabi and Liñán (2013).

The consumer/citizen orientation comprised four variables, and the overall average of the responses was 2.88 , within the area of disagreement with the statements presented. This finding shows that consumers' desires and needs in the markets, as well as those of citizens in general, are not considered so widely in Brazilian public universities. This confirms that interaction with markets has not naturally occurred in the academic environment (Siegel, Waldman, Atwater, \& Link, 2004), setting aside the focus on the consumer/citizen in the body of research developed in the context of Brazilian public universities, which seems inconsistent with the role demanded of such institutions in current times (Calderon-Martinez \& Garcia-Quevedo, 2013; Marozau et al., 2016).

In turn, the entrepreneurial orientation showed the lowest mean score among all the factors covered in this study (2.27), demonstrating the scant attention and stimulus to entrepreneurship occurring in the environment of research in Brazilian public universities. Such a situation weakens the marketing role and obstructs an alternative in order for determinate technologies to obtain success in the markets, through formation of university spinoffs/startups (Payumo et al., 2012).

Finally, among all the factors included in this study, the technology orientation presented the highest average score of responses (3.29). Despite being next to the neutrality zone, some tendency to agreement was shown, compared with the other dimensions presented. Such a situation, associated with the TICs' typical focus on intellectual protection, contributes to a distorted vision of the market, generating a wrong sense of value of the technologies produced in universities. This is because such a vision prioritizes the generation of patents, which naturally incurs costs but does not always obtain the desired market success (Hall, Matos, Bachor, \& Downey, 2014; Mohr \& Sarin, 2009).

\section{Marketing practices used to promote the technologies' commercialization}

To attain the fourth specific objective of this work (to identify the marketing practices used to promote commercialization of the technologies developed in the context of Brazilian public universities), a relationship was developed among 14 variables. The respondents were instructed to indicate their degree of agreement or disagreement with the statements on a five-point scale, ranging from 1 = "never" to 5 = "very often." Table 3 presents the results, listed in the order of agreement by the respondents. 
Table 3. Marketing practices used to promote the technologies' commercialization

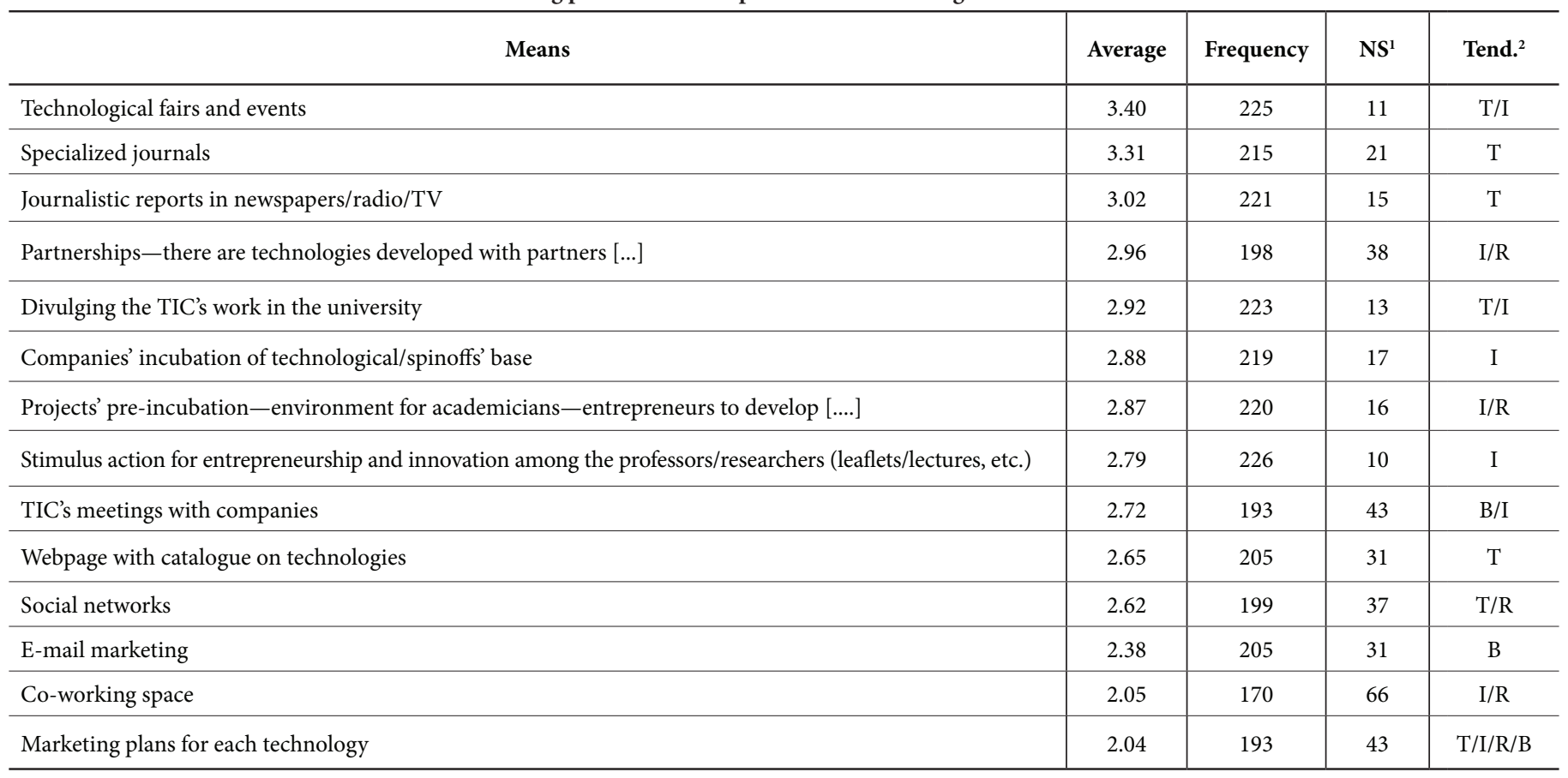

${ }^{1}$ NS: Did not know. ${ }^{2}$ Tend.: Tendency. T: Transactional. B: Database. I: Interactive. R: Network.

Source: Research data

The marketing practice that received the highest score involved "technical fairs and events," with an average of 3.40, followed by "specialized journals" (3.31) and "journalistic reports in newspapers/radio/ TV" (3.02). Considering the contemporary marketing practices proposed by Coviello and colleagues (2002), it is verified that in a relatively weak way, the three best practices highlighted by the respondents tend to be transactional. Among these, the most prominent-the exposure of technologies in "technical fairs and events"-as well as the transactional aspects, could be considered interactive, by allowing the beginning of an interaction between universities/TICs and companies/entrepreneurs willing to license technologies or expand relationships for future research.

On the other hand, the practice of creating a marketing plan for each technology, allowing the identification of specific strategies to enhance the results of the technology transfer/marketing, exhibited the lowest overall average of the responses (2.04). Additionally, 43 people were unable to respond to this question, demonstrating their ignorance about the potential contributions of developing marketing plans for the commercialization of each technology.

The development of technologies through "partnerships [...]" had an overall average response of 2.96; however, 38 scholars did not know how to answer the question. This confirms Stal and Fujino's (2016) considerations regarding the non-verification of an improvement in cooperation between universities and companies in Brazil over the last decades.
Overall, this study's participants perceive that the universities' marketing practices that aim to promote the commercialization of technologies that are developed based on academic research are quite limited. Thus, they understand that not even the developed technologies have received due attention so that they could fulfill the needs, desires, and demands of society and/or the market (Calderon-Martinez \& Garcia-Quevedo, 2013; Marozau et al., 2016; Siegel \& Wright, 2015; Stal \& Fujino, 2016).

\section{Obstacles to marketing from research until commercializa- tion of technologies in Brazilian public universities}

The fifth and last specific goal of this study was to know the obstacles faced by marketing from the research until the commercialization of technologies in Brazilian public universities. To this end, a list of 19 variables was made, based on the relevant literature (Kaymaz \& Eryiğit, 2011; Klein et al., 2010; Nabi \& Liñán, 2013; Siegel et al., 2003; Siegel et al., 2004; Veroneze, 2016). The respondents were asked to indicate their degree of agreement/disagreement with the statements on a five-point scale, with the same range of items as those of the previous ones. The main findings on such obstacles are presented and discussed in the sequence.

The point with the respondents' greater agreement on the obstacles to marketing was "the bureaucracy and the inflexibility of the administrators of the university", with an average of 4.29. This brings to the fore the need to develop practices for the management of intellectual property in universities, which is possibly at an embryonic stage in Brazil (Siegel et al., 2003; Veroneze, 2016). 
The problem regarding the scarce development of the relationships between universities and companies in Brazil is also evidenced by the high overall average (4.19) received by the "lack of communication between the university and companies." The "lack of resources aimed at technology transfer from the university" (4.03) is also noteworthy, confirming some studies' reported findings about the TICs' lack of material and human resources and the minimal or non-existent training in business and marketing provided to the TICs' personnel (Hsu et al., 2015; Veroneze, 2016; Weckowska, 2015).

The "lack of stimulus to entrepreneurship in the academic environment", average (4.02), is an obstacle that can undermine entrepreneurship as a path for the availability of university technologies to the market and society (Payumo et al., 2012).

The strong discordance (4.00) that the "insufficient benefits to professors/researchers from the university on technology transfer" can contribute to the weakening of commercialization of technologies because professors/researchers are pointed out as key actors in the transfer of technologies (Markman, Gianiodis, Phan, \& Balkin, 2005).

The "legislation (laws, standards, and regulations) creates difficulties for the commercialization of technologies" was the sixth most relevant obstacle (3.96), followed by the "insufficient publicity for mutual possibilities offered by the university and companies" (3.91), which must be objects of attention by Brazilian public universities and legislators.

Finally, it should be emphasized that the respondents' perceptions on the "university distancing itself from society's demands for new technologies" (3.78) show their opposition to the current role expected of universities (Calderon-Martinez \& Garcia-Quevedo, 2013; Marozau et al., 2016). The respondents are also against the most current definitions of marketing and its relationship with the context of academic research for the development of technologies (Levitt, 2004; Sousa et al., 2015; Wirtz et al., 2014).

This whole scenario demonstrates the large and complex obstacles faced by marketing from the survey until the commercialization of technologies in Brazilian public universities. This situation demands rethinking of management practices and public policies on science and technology in public universities.

\section{Discussion}

The goal of understanding the role of marketing, from research until commercialization of technologies in Brazilian public universities, has been reached, according to the perceptions of the survey respondents, composed mostly of professors/researchers with patents. The data obtained has allowed an analysis from the perspective of individuals directly involved in the development of new technologies from academic research. Most of the professors/researchers with patents have neither undertaken research under contract nor consulting work, showing their distance from the market and society.
The EFA has allowed the identification of six factors that contribute to the perception of the fragility of the market approach in Brazilian public universities. An important point lies in providing guidance for technologies, specifically those oriented to the consumer/citizen and the entrepreneur. This demonstrates that the technology/product itself has been the main driver of research, neglecting the needs of the market and society (Baker, 2003; Bodlaj, 2012; Levitt, 2004). In this sense, the universities need to develop marketing capabilities to enable them to anticipate and act on changes in markets and society. They should do so from a long-term perspective, in an active and relevant way, with the aim of contributing more directly to the economic and technological development in Brazil (Baker, 2003; Mu, 2015; Mu \& Di Benedetto, 2011).

The results indicate the weak and predominantly transactional marketing practices that are used to promote commercialization of the technologies developed in Brazilian public universities, corroborating the imbalance of marketing in the analyzed context. Even the technologies that are already developed have received insufficient or inappropriate attention for marketing purposes.

The obstacles to marketing (from research until commercialization of the technologies highlighted by the respondents) highlight the need for changes in the management of these institutions to align with the new demands imposed on them in current times (Calderon-Martinez \& Garcia-Quevedo, 2013; Kaymaz \& Eryiğit, 2011; Marozau et al., 2016; Nabi \& Liñán, 2013; Siegel et al., 2003).

To paraphrase Levitt (2004), the results obtained jointly lead to the conclusion that (limited to the general perception of this sample) in Brazilian public universities, marketing efforts are still considered necessary consequences of the product/technology developed, not the product/technology as a consequence of marketing, as it should be, leading to an evident marketing myopia, from research to commercialization of technologies.

A limitation of this study concerns the sampling by convenience and accessibility to respondents, which makes it non-probabilistic, limiting the extrapolation of the results. The lack of a culture of research geared to the needs, desires, and demands of society and the market may have restricted the academicians' ability to respond to this survey. Additionally, for the sake of the schedule for the development of this study, the data were collected from November 2016 to January 2017, corresponding to the vacation period in public universities. It is believed that if the collection was done at other times, the response rate would have been higher.

It is suggested that new studies be conducted from the marketing perspective, particularly to deepen the knowledge about the professors/researchers who have transferred/licensed technologies and/or have a stake in spinoff/startup university companies. Another suggestion for future research would be to use the theoretical bases of organizational culture to understand more deeply the aspects related to the values, beliefs, habits, assumptions, and traditions in Brazilian 
public universities and apparently affect the adoption of marketing, from research to commercialization of technologies in Brazilian public universities.

This work's main academic contribution is the implementation of a framework of studies built on a large body of literature, involving marketing, entrepreneurship, and issues concerning technology transfer from universities (Bodlaj, 2010; Bouncken et al., 2016; Coviello et al., 2002; Jeong et al., 2006; Kaymaz \& Eryiğit, 2011; Kerr \& Patti, 2015; Malvezzi et al., 2014; Matsuno et al., 2014; Mu, 2015; Nabi \& Liñán, 2013; Siegel et al., 2003). With such fragility of marketing, it is suggested that these institutions, especially through the development of physical structures, people, and processes of TICs' management, apply the strategies and concepts already consolidated in marketing, aiming to offer the researchers the knowledge and marketing interaction relevant for their research.

\section{References}

American Marketing Association. (2015). Definition of marketing (approved July 2013). Retrieved from https://www.ama.org/abouta$\mathrm{ma} /$ pages/definition-of-marketing.aspx.

Antonialli, F., Antonialli, L. M., \& Antonialli, R. (2017). Uses and abuses of the Likert scale: bibliometric study in the proceedings of Enanpad from 2010 to 2015. Reuna, 22(4), Oct-Dec, 1-18.

Baker, M. J. (2003). Marketing book. Oxford: Butterworth-Heinemann.

Becker, M. C., \& Lillemark, M. (2006). Marketing/R\&D integration in the pharmaceutical industry. Research Policy, 35(1), 105-120. doi: http://doi.org/10.1016/j.respol.2005.09.005.

Bodlaj, M. (2010). The impact of a responsive and proactive market orientation on innovation and business performance. Economic and Business Review, 12(4), 241-261.

Bodlaj, M. (2012). Do managers at two hierarchical levels differ in how they assess their company's market orientation? Journal for East European Management Studies, 17(3), 292-312.

Boehm, D. N., \& Hogan, T. (2013). Science-to-business collaborations: A science-to-business marketing perspective on scientific knowledge commercialization. Industrial Marketing Management, 42(4), 564579. doi: http://doi.org/10.1016/j.indmarman.2012.12.001.

Bouncken, R. B., Plüschke, B. D., Pesch, R., \& Kraus, S. (2016). Entrepreneurial orientation in vertical alliances: Joint product innovation and learning from allies. Review of Managerial Science, 10(2), 381409. doi: http://doi.org/10.1007/s11846-014-0150-8.

Brodie, R. J., \& Coviello, N. E. (2008). Contemporary marketing practices research program: A review of the first decade. Journal of Business \& Industrial Marketing, 23(2), 84-94.
Calderon-Martinez, M. G., \& Garcia-Quevedo, J. (2013). Knowledge transfer and university patents in Mexico. Academia-Revista Latinoamericana De Administracion, 26(1), 33-60. doi: http://doi. org/10.1108/arla-05-2013-0039.

Coviello, N. E., Brodie, R. J., Danaher, P. J., \& Johnston, W. J. (2002). How firms relate to their markets: An empirical examination of contemporary marketing practices. Journal of Marketing, 66(3), 33-46.

Coviello, N. E., Brodie, R. J., \& Munro, H. J. (1997). Understanding contemporary marketing: Development of a classification scheme. Journal of Marketing Management, 13(6), 501-522. doi: http://dx.doi. org/10.1080/0267257X.1997.9964490

Field, A. (2009). Descobrindo a estatística usando o SPSS (2nd ed.). Porto Alegre: Artmed/Bookman.

Griffin, A., \& Hauser, J. R. (1996). Integrating R\&D and marketing: A review and analysis of the literature. Journal of Product Innovation Management, 13(3), 191-215.

Gummesson, E. (1991). Marketing orientation revisited: The crucial role of the part-time marketer. European Journal of Marketing, 25(2), 60-75. doi: http://doi:10.1108/03090569110139166.

Hair Jr., J. F., Anderson, R. E., Tatham, R. L., \& Black, W. C. (2005). Análise Multivariada de Dados (5th ed.). Porto Alegre: Bookman.

Hakala, H. (2011). Strategic orientations in management literature: Three approaches to understanding the interaction between market, technology, entrepreneurial and learning orientations. International Journal of Management Reviews, 13(2), 199-217. https://doi. org/10.1111/j.1468-2370.2010.00292.x.

Hall, J., Matos, S., Bachor, V., \& Downey, R. (2014). Commercializing university research in diverse settings moving beyond standardized intellectual property management. Research-Technology Management, 57(5), 26-34. http://doi.org/10.5437/08956308x5705250.

Hsu, D. W. L., Shen, Y.-C., Yuan, B. J. C., \& Chou, C. J. (2015). Toward successful commercialization of university technology: Performance drivers of university technology transfer in Taiwan. Technological Forecasting and Social Change, 92, 25-39. https://doi.org/10.1016/j. techfore.2014.11.002.

Ismail, N., Nor, M. J. M., \& Sidek, S. (2015). A framework for a successful research products commercialisation: A case of Malaysian academic researchers. Procedia - Social and Behavioral Sciences, 195, 283-292.

Jeong, I., Pae, J. H., \& Zhou, D. S. (2006). Antecedents and consequences of the strategic orientations in new product development: The case of Chinese manufacturers. Industrial Marketing Management, 35(3), 348-358. https://doi.org/10.1016/j.indmarman.2005.06.010 
Kaymaz, K., \& Eryiğit, K. Y. (2011). Determining factors hindering university-industry collaboration: An analysis from the perspective of academicians in the context of entrepreneurial science paradigm. International Journal of Social Inquiry, 4(1), 185-213.

Kerr, G., \& Patti, C. (2015). Strategic IMC: From abstract concept to marketing management tool. Journal of Marketing Communications, 21(5), 317-339.

Klein, R., Haan, U., \& Goldberg, A. I. (2010). Overcoming obstacles encountered on the way to commercialize university IP. Journal of Technology Transfer, 35(6), 671-679. doi: http://doi.org/10.1007/ s10961-009-9143-1.

Kliewe, T., Baaken, T., \& Kesting, T. (2012). Introducing a scienceto-business marketing unit to university knowledge and technology transfer structures: Activities, benefits, success factors. In A. Szopa, W. Karwowski, \& P. O. D. Pablos (Eds.), Academic entrepreneurship and technological innovation: A business management perspective (1st ed., pp. 53-74). Hershey, PA, IGI Global.

Kotler, P. (1972). A generic concept of marketing. Journal of Marketing, 36(2), 46-54. doi:10.2307/1250977

Lee, D. (2013). What is marketing? Public Services Quarterly, 9(2), 169-171. doi:10.1080/15228959.2013.785900

Levitt, T. (2004). Marketing myopia. Harvard Business Review, 82(7/8), 138-149.

Malhotra, N. K., Rocha, I., Laudisio, M. C., Altheman, É., \& Borges, F. M. (2005). Introdução à pesquisa de marketing. São Paulo: Pearson Prentice Hall.

Malvezzi, F. d. A., \& Zambalde, A. L. (2013). Abordagem de marketing no processo de inovação tecnológica em uma universidade mineira. Revista FSA, 10(1), 25-39.

Malvezzi, F. d. A., Zambalde, A. L., \& Rezende, D. C. d. (2014). Marketing de patentes à inovação: Um estudo multicaso em universidades brasileiras. REMark, 13(5), 109-123.

Markman, G. D., Gianiodis, P. T., Phan, P. H., \& Balkin, D. B. (2005). Innovation speed: Transferring university technology to market. Research Policy, 34(7), 1058-1075. doi: http://doi.org.10.1016/j.respol.2005.05.007.

Marozau, R., Guerrero, M., \& Urbano, D. (2016). Impacts of universities in different stages of economic development. Journal of the Knowledge Economy, 1-21. doi: http://doi.org/10.1007/s13132-0160359-7.

Matsuno, K., Zhu, Z., \& Rice, M. P. (2014). Innovation process and outcomes for large Japanese firms: Roles of entrepreneurial proclivity and customer equity. Journal of Product Innovation Management, 31(5), 1106-1124. doi: http://doi.org/10.1111/jpim.12147.
Mohr, J. J., \& Sarin, S. (2009). Drucker's insights on market orientation and innovation: Implications for emerging areas in high-technology marketing. Journal of the Academy of Marketing Science, 37(1), 85-96. doi: http://doi.org/10.1007/s11747-008-0101-5.

$\mathrm{Mu}$, J. (2015). Marketing capability, organizational adaptation and new product development performance. Industrial Marketing Management, 49, 151-166. doi: http://doi.org/10.1016/j.indmarman.2015.05.003.

Mu, J., \& Di Benedetto, C. A. (2011). Strategic orientations and new product commercialization: Mediator, moderator, and interplay. $R$ \& D Management, 41(4), 337-359.

Nabi, G., \& Liñán, F. (2013). Considering business start-up in recession time: The role of risk perception and economic context in shaping the entrepreneurial intent. International Journal of Entrepreneurial Behavior \& Research, 19(6), 633-655.

Narver, J. C., \& Slater, S. F. (1990). The effect of a market orientation on business profitability. Journal of Marketing, 54(4), 20-35. doi: http://doi.org/10.2307/1251757.

Payumo, J., Gang, Z., Pulumbarit, E., Jones, K., Maredia, K., \& Grimes, H. (2012). Managing intellectual property and technology commercialization: Comparison and analysis of practices, success stories and lessons learned from public research universities in developing Asia. Innovation-Management Policy \& Practice, 14(4), 478-494.

Pereira, R. D. S., Franco, I. D., Santos, I. C., \& Vieira, A. M. (2015). Ensino de inovação na formação do administrador brasileiro: Contribuições para gestores de curso. Administração: Ensino e Pesquisa, 16(1), 101-139.

Siegel, D. S., Waldman, D. A., Atwater, L. E., \& Link, A. N. (2004). Toward a model of the effective transfer of scientific knowledge from academicians to practitioners: Qualitative evidence from the commercialization of university technologies. Journal of Engineering and Technology Management, 21(1-2), 115-142. doi: http://doi. org/10.1016/j.jengtecman.2003.12.006.

Siegel, D. S., Waldman, D., \& Link, A. (2003). Assessing the impact of organizational practices on the relative productivity of university technology transfer offices: An exploratory study. Research Policy, 32(1), 27-48. doi: http://doi.org/10.1016/s0048-7333(01)00196-2.

Siegel, D. S., \& Wright, M. (2015). Academic entrepreneurship: Time for a rethink? British Journal of Management, 26(4), 582-595. doi: http://doi.org/10.1111/1467-8551.12116.

Smith, N. C., Drumwright, M. E., \& Gentile, M. C. (2010). The new marketing myopia. Journal of Public Policy \& Marketing, 29(1), 4-11. doi: http://doi.org/10.1509/jppm.29.1.4.

Sousa, D., Veroneze, R. B., Zambalde, A. L., \& Bermejo, P. H. d. S. (2015). Relations between marketing and innovation in Brazilian universities. Lecture Notes in Computer Science, 9265, 379-389. 
Stal, E., \& Fujino, A. (2016). The evolution of universities' relations with the business sector in Brazil: What national publications between 1980 and 2012 reveal. Revista de Administração (São Paulo), 51(1), 72-86. doi: http://doi.org/10.5700/rausp1224.

Veroneze, R. B. (2016). Marketing desde a pesquisa até a comercialização de tecnologias em universidades: Um estudo multicaso. (Dissertação de mestrado), Universidade Federal de Lavras, Lavras, MG, Brasil.

Veroneze, R. B., Zambalde, A. L., Sousa, D. d., \& Rennó, A. S. (2017). As relações entre a universidade e o mercado sob a perspectiva do marketing: Uma revisão sistemática de literatura. Revista Foco, 10(1), 195-220.
Weckowska, D. M. (2015). Learning in university technology transfer offices: Transactions-focused and relations-focused approaches to commercialization of academic research. Technovation, 41-42, 62-74. doi: http://doi.org/10.1016/j.technovation.2014.11.003.

Wirtz, J., Tuzovic, S., \& Kuppelwieser, V. G. (2014). The role of marketing in today's enterprises. Journal of Service Management, 25(2), 171-194. 